\title{
GENDER PAY GAP: A MYTH OR MATH
}

\author{
Dr. Hitesh N. Jagani \\ Dr. Nasheman Bandookwala
}

\begin{abstract}
Gender discrimination has been persistent across globe and it is more identified in terms of wage differential. Such discrimination is more striking in developing countries and further more among social groups. Though many countries have passed minimum wage laws and laws mandating equal treatment of women at workplace, gender wage differential remains a perennial feature of labor markets across globe. Among BRIC nation India depicts highest wage discrimination between sexes (Rema Nagarajan TNN March 2011). This fact was reveled also in the Global Gender Gap Report of 2010 as well. The recent survey by the World Economic Forum (WEF) points out the Indian situation, ranking India among the bottom 10 countries in the world in terms of women's participation in the economy. The World Economic Forum's Global Gender Gap Report 2020 says Of the 153 countries studied in the report, India ranks 112th on the overall Global Gender Gap Index with the index value of (0.068). The overall gender gap as though has narrowed the pay gaps have widen and it will take 257 more years i.e by year 2257 pay equity will be established. India has shown disappointing performance in women work participation rate (WPR), pushing the country among the bottom 10 countries on the WEF list. The country ranks $149^{\text {th }}$ among 153 countries in economic participation. Overall, in terms of gender equality India achieves a score of $59.4 \%$, but in terms of economic participation and opportunity, it scores $39.8 \%$ which is dismal.
\end{abstract}

The present study is an attempt to analyze the wage differential across selected states of India. The wages for agriculture and non agriculture workers for sexes is considered. The attempt has been made to evaluate wage differential across selected states of India and inequality therein has been calculated. The descriptive statistical tools like arithmetic mean and standard deviation has been used to ameliorate understanding. The pay parity Index has also been calculated

The overall observation from the study widens understanding about pay pattern in India - and discriminating dimension therein. Across occupation unequal pay prevails in regards to sexes with males being paid more than women for the equal jobs. Disparity among agricultural 
workers is highest at Kerala- female agricultural workers are paid $29 \%$ less than males. On other hand in Himachal Pradesh male agricultural worker is paid 5\% less than females. For non agricultural workers Tamil Nadu exhibits high incidence of inequality with female workers being paid $32 \%$ less than males. Gujarat comparatively depicts a better scenario with average female payments being more in non agricultural sector as though in agriculture sector disparity prevails.

Key words: wage differential, pay parity, Gender wage gap

\section{Prologue}

Women population constitutes half of the country's population accounting for 586 million in absolute number as per 2011 census. The women population in India is characterized by low literacy rate (53\%), low work participation rate of 33\% for rural and $17 \%$ urban and low level of development participation ( 2011 census). More than $90 \%$ of the women in rural areas and $69 \%$ in urban areas were found having no technical skills (census 2011). Women in India is recognized as a source of inexpensive and alternate labor that can be hired and fired at a will of an employer. The potential empowering and liberating would be realism only if women is given equal opportunity and equal pay whilst unequal and low pay adds to drudgery. Post independence era the policies has placed women at pedestal embarking women centric development. But till recent both in developed and in developing countries, the discrimination against women continues. Gender is considered the most important factor as far as Indian labour market is concerned and discrimination in terms of wage payment is perennial across sectors. According to SEWA (Self Employed Women s Association 2000) the wages of women workers were below the minimum wages in some cases and the average monthly income of women workers was Rs 1815 compared to 3842 for male workers which accounts to $52 \%$ of disparity. Researchers have been quoted various reasons for disparity in pay package of which some are briefed:

- Women mostly work in light industrial units as they are unfit for work in heavy industries that needs more physical strength. Additionally, predominantly women work in unorganized sector where the wages tends to be very low. About $94 \%$ of the total working women are in unorganized sector (ICSSR, Status of Women in India, 1971-74, p.63.).

- Physically women are not as strong as men and thus are incapable to work for longer hours, that results into lower payments compared to their men counterparts.

- Finally, in case of physical or less mental work male workers tend to improve their productivity by undergoing long hours on the job training or otherwise whilst women have many other priorities like family care and child care and thus are unable to undergo such training which makes them less productive than their male rewarding them lower pay package for lesser productivity. 


\section{Related Literature}

Even after the formation of equal remuneration act which guarantees equal rights to women in terms of wages as compared to male counterparts, it is clearly visible that the women labour is still paid lesser wages than male counterparts for the same type of work- more precisely even in technical jobs (mental jobs). Nonetheless it is understandable to have lesser payments for physical jobs but why for mental jobs were disability factor does not enters? During the past few years an increasing trend has been observed both in wages and income of the people but when it come to wage differentials we do not find any significant change (Dev, 2002). Further analysis have shown that higher education levels women rate is not only increasing but they are also out performing men but when one looks at the gender disparity as per education level we find the this gap is still widening (Rustagi, 2003). Various studies on the labour market in India which have linked wage rate with the average productivity of labour and have tried to determine the wage rate differentials through these facts but all these studies have proved to be inadequate to explain variations in wage rates across India (Bhalla, 2000). As per NSSO report the Gender Pay Gap (GPG) has seen an increasing trend after liberalization as the GPG has increased from 24\% in 1991 to about 32\% in 2004 where as residual gap has increased from 53\% to 78\% ( Menon and Rodger 2009). Women in rural areas faces various form of discrimination including job typing pushes them to low paying jobs Women work may be part time or full time is rooted in diverse cultural, social, economical and personal factors in developing countries (N Srivatava and R Srivastava)

\section{Wage differential In India}

Wage differential in India or gender pay gap has varied flavor with socioeconomic and structural factors linked to it. Women in India remain out of work for family reasons ranging from childcare to healthcare of family members. Girl children are dropped from school for need of household chores with the belief that learning and fulfilling duties towards family is priority vis a vis acquiring formal education that ultimately keep them out of workforce. Instances of family not allowing women to go for work are very many in the country and adds fuel to fire. All these and many known unknown reasons adds onto women lagging behind her men counterparts in terms of economic independence. The Monster salary Index (MSI), 2019 reported women in India earns 19\% less than men. The average hourly salary of women being Rs.196.3 per hour whilst men being RS. 242.49 per hours accounting to the gap of Rs.42.49. The gender pay gap is in all sectors of Industries but IT sector top the list with $24 \%$ more in favour of men. The scenario is further depressing in unorganized agriculture sector where women is routinely paid lesser than her men counterparts citing reasons like difference in capability and productivity or constraints in terms of performing physical work. Across states of India wage differential have been exhibited in the Table 1 for Agricultural and non Agricultural workers between sexes 
Towards Excellence: An Indexed, Refereed \& Peer Reviewed Journal of Higher Education / Dr. Hitesh Jagani \& Dr. Nasheman Bandookwala / Page 399-410

Table: 1 State wise differential in daily wages paid to Agricultural and Non agricultural workers 2011

\begin{tabular}{|c|c|c|c|c|c|c|}
\hline \multirow[t]{2}{*}{ States } & \multicolumn{2}{|c|}{ Agricultural } & \multirow[b]{2}{*}{ Gap } & \multicolumn{2}{|c|}{ Non Agricultural } & \multirow[b]{2}{*}{ Gap } \\
\hline & Male & Female & & Male & Female & \\
\hline AP & 208.25 & 135.25 & 73 & 221.03 & 162.11 & 58.92 \\
\hline Assam & 192.35 & 176.67 & 15.68 & 202.18 & 180 & 22.18 \\
\hline Bihar & 184.05 & 146.83 & 37.22 & 206.51 & 191.67 & 14.84 \\
\hline Gujarat & 141.9 & 137.67 & 4.23 & 173.42 & 175.83 & -2.41 \\
\hline Haryana & 328.18 & 325.71 & 2.47 & 324.55 & NA & 0 \\
\hline $\begin{array}{l}\text { Himachal } \\
\text { Pradesh }\end{array}$ & 288.14 & 302 & -13.86 & 260.8 & NA & 0 \\
\hline $\mathrm{J} \& \mathrm{~K}$ & 346.82 & NA & 0 & 347.19 & NA & 0 \\
\hline Karnataka & 200.6 & 142.5 & 58.1 & 212.14 & 157.73 & 54.41 \\
\hline Kerala & 587.95 & 417.98 & 169.97 & 603.74 & NA & 0 \\
\hline MP & 143.84 & 124.9 & 18.94 & 143.04 & 110 & 33.04 \\
\hline Maharashtra & 190.78 & 127.3 & 63.48 & 200.89 & 114.44 & 86.45 \\
\hline Manipur & NA & NA & 0 & $\mathrm{NA}$ & NA & 0 \\
\hline Meghalaya & 176.25 & 126.25 & 50 & 194.44 & NA & 0 \\
\hline Orissa & 170.77 & 156.84 & 13.93 & 165 & 164 & 1 \\
\hline Punjab & 279.4 & NA & 0 & 261 & NA & 0 \\
\hline Rajasthan & 247.33 & 201.67 & 45.66 & 259.55 & NA & 0 \\
\hline Tamil Nadu & 321.67 & 179.03 & 142.64 & 368.12 & 251.13 & 116.99 \\
\hline Tripura & 210 & NA & 0 & 200 & NA & 0 \\
\hline UP & 181.98 & 155.27 & 26.71 & 208.64 & 177.73 & 30.91 \\
\hline West Bengal & 203.84 & 175.24 & 28.6 & 199.6 & 170.77 & 28.83 \\
\hline India & 215.7 & 154.57 & 61.13 & 232.41 & 172 & \\
\hline
\end{tabular}

Source WWW. Indiastat

Surprisingly all the state of India exhibits lower remuneration to female than their male counterparts in both the activities viz. agriculture and non agriculture. It would be interesting to analyse states with highest and lowest remuneration to female .The highest gap in agricultural sector is registered in Kerela while lowest is in Himachal Pradesh with women being paid more than men. For non agricultural sector highest gap is recorded in Tamil Nadu while Gujarat records more payment to women against male. The Table 2 depicts ranking of the states for both the activities in terms of absolute payments.

\section{Chart :1 State wise agricultural and Non Agricultural wages for Male and female}




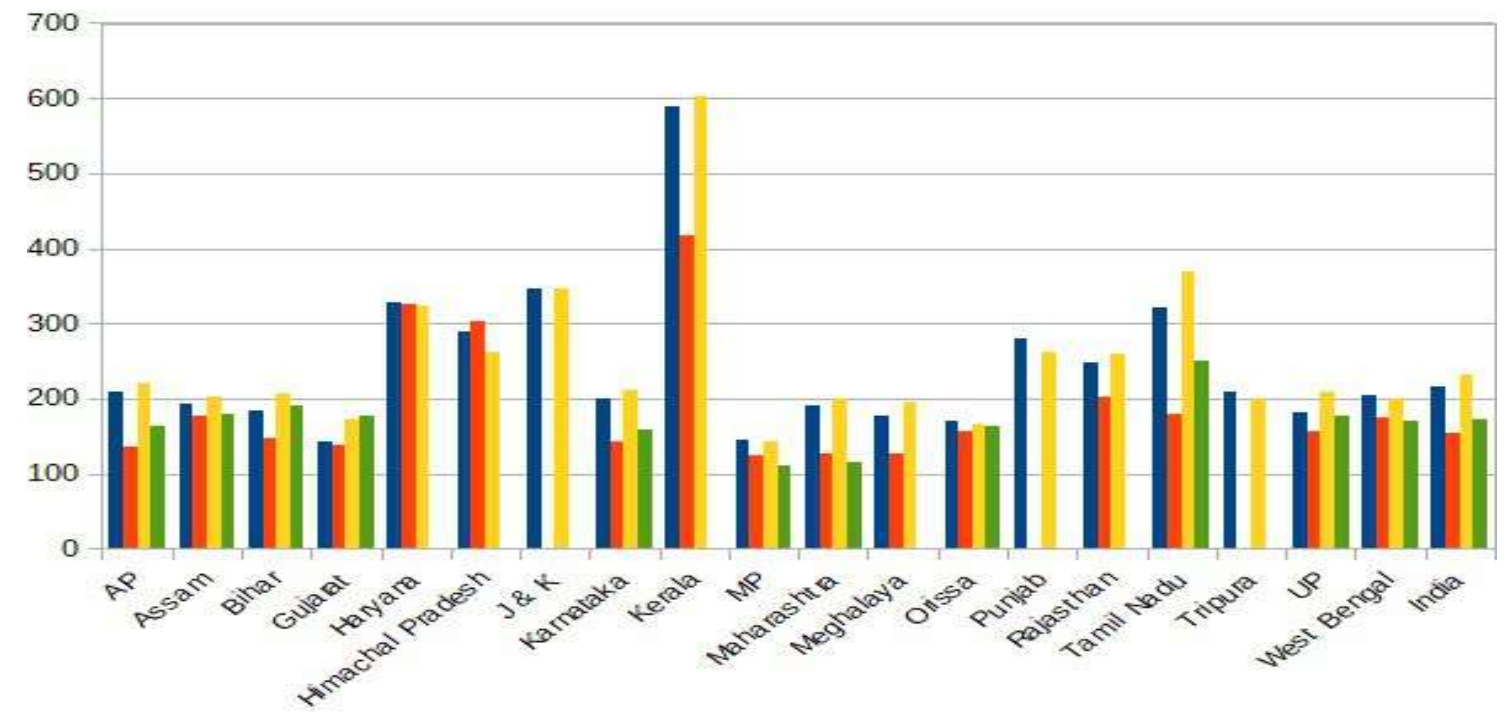

The ranking has been done on ascending order basis meaning state with lowest wage payment is awarded with $1^{\text {st }}$ rank and that of highest paying states gets last rank. For both the activities Madhya Pradesh has $1^{\text {st }}$ rank indicating state with lowest payment to females. However, southern India states Kerala and Tamil Nadu among states of India is highest paying states to female for agricultural and non agricultural activities respectively. Whilst these southern states although pay handsome the gap in both the sates is highest endorsing the fact the while payments are more along with higher gap in payments. Gujarat stands on $5^{\text {th }}$ rank for agricultural wages and $7^{\text {th }}$ rank for non agricultural wages. Surprisingly, Maharashtra is on $2^{\text {nd }}$ and $3^{\text {rd }}$ rank for agricultural and non agricultural wages respectively.

Table : 2 Ranking states for female wages

\begin{tabular}{|l|r|r|}
\hline States & Wages in Agriculture & Wages in Non Agriculture \\
\hline AP & 4 & 4 \\
\hline Assam & 11 & 9 \\
\hline Bihar & 7 & 10 \\
\hline Gujarat & 5 & 7 \\
\hline Haryana & 15 & $@$ \\
\hline Himachal Pradesh & 14 & $@$ \\
\hline J \& K & $@$ & $@$ \\
\hline Karnataka & 6 & 3 \\
\hline Kerala & 16 & $@$ \\
\hline Maharashtra & 3 & 2 \\
\hline Manipur & $@$ & $@$ \\
\hline Meghalaya & 2 & $@$ \\
\hline
\end{tabular}


Towards Excellence: An Indexed, Refereed \& Peer Reviewed Journal of Higher Education / Dr. Hitesh Jagani \& Dr. Nasheman Bandookwala / Page 399-410

\begin{tabular}{|c|c|c|}
\hline Madhya Pradesh & 1 & 1 \\
\hline Orissa & 9 & 5 \\
\hline Punjab & (a) & @ \\
\hline Rajasthan & 13 & (a) \\
\hline Tamil Nadu & 12 & 11 \\
\hline Tripura & (a) & (a) \\
\hline UP & 9 & 8 \\
\hline West Bengal & 10 & 6 \\
\hline
\end{tabular}

Source: Calculated

@ Data unavailable

\section{Inequality in wages between sexes}

High incidence of inequality has been recorded between sexes in wage payment. The highest inequality is recorded at Tamil Nadu for agriculture activity and at Maharashtra for non agricultural activity. Himachal Pradesh exhibits higher payments to female compared to male in agriculture sector and Gujarati females are paid more than their counterparts in non agricultural activities.(Table 3)

Table 3 Inequality in wage payment between sexes

\begin{tabular}{|l|r|r|}
\hline States & Inequality in Agriculture & Inequality in Non Agriculture \\
\hline AP & 0.351 & 0.267 \\
\hline Assam & 0.082 & 0.110 \\
\hline Bihar & 0.202 & 0.072 \\
\hline Gujarat & 0.030 & -0.014 \\
\hline Haryana & 0.008 & $@$ \\
\hline Himachal Pradesh & -0.048 & $@$ \\
\hline J \& K & 0 & 0 \\
\hline Karnataka & 0.290 & 0.256 \\
\hline Kerala & 0.289 & $\vdots$ \\
\hline Maharashtra & 0.132 & 0.430 \\
\hline Manipur & $@$ & $@$ \\
\hline Meghalaya & 0.334 & 0 \\
\hline MP & 0.284 & 0.231 \\
\hline Orissa & 0.082 & 0.006 \\
\hline Punjab & $@$ & $@$ \\
\hline Rajasthan & 0.185 & $@$ \\
\hline Tamil Nadu & 0.443 & 0.318 \\
\hline Tripura & $@$ & $@$ \\
\hline UP & 0.147 & 0.148 \\
\hline
\end{tabular}




\begin{tabular}{|l|r|r|}
\hline West Bengal & 0.140 & 0.144 \\
\hline India & 0.283 & 0.260 \\
\hline
\end{tabular}

Source Calculated

(a) Data unavailable

It is note worthy that average wages paid to females in both the activities viz. agriculture and non agriculture is $28.3 \%$ and $26.0 \%$ respectively lesser than males. While average wage paid to males in agricultural is Rs 242.32 that to women is Rs 189.44. Moreover, median wages to male is 206.045 that to women is 155.27 calculating to inequality of $24.64 \%$ for agricultural labour and in-case of non-agricultural labour median wages for male workers are 210.39 that of women is 171.385 calculating the inequality of $18.53 \%$ Table 4 .

Table 4 Parameters of wages

\begin{tabular}{|c|c|c|c|c|}
\hline Parameters & Agriculture Male & $\begin{array}{l}\text { Agriculture } \\
\text { Female }\end{array}$ & $\begin{array}{l}\text { Non Agriculture } \\
\text { Male }\end{array}$ & $\begin{array}{l}\text { Non Agriculture } \\
\text { Female }\end{array}$ \\
\hline Average & 242.3211 & 189.4444 & 250.0968 & 168.6736 \\
\hline Median & 206.045 & 155.27 & 210.39 & 171.385 \\
\hline $\begin{array}{l}\text { Standard } \\
\text { Deviation }\end{array}$ & 103.9315 & 84.84426 & 104.7873 & 37.63292 \\
\hline $\begin{array}{l}\text { Co-efficient of } \\
\text { varation }\end{array}$ & 42.89 & 44.78584 & 41.89869 & 22.31109 \\
\hline
\end{tabular}

Deviation in male wages is 103 and 104 respectively across states of India for agriculture and non agriculture activities. While for women the standard deviation is 84.84 and 37.63 receptively for agricultural and non agricultural wages indicating in non agricultural sector among women employee the deviation or inequality tends to be less. The coefficient of variation for female non agricultural workers is 22.31 while for male it $\mathrm{n}$ is 41.89 that confirms that there exist high incidence of inequality in men employee payments in non agricultural sector. In agricultural sector co-efficient of variation in female workers across sates of India is 44.786 indicating sharp inequality in payments.

\section{Pay Parity Index}

Pay index has been calculated taking highest wage across states for agricultural activities and lowest wage in the same activity. Similarly for non agricultural activity

Table 5 Pay Parity Index

\begin{tabular}{|l|l|l|l|l|}
\hline States & Agriculture & Non Agriculture & $\begin{array}{l}\text { Pay Parity } \\
\text { Agriculture }\end{array}$ & $\begin{array}{l}\text { Pay Parity } \\
\text { Non }\end{array}$ \\
\hline
\end{tabular}


Towards Excellence: An Indexed, Refereed \& Peer Reviewed Journal of Higher Education / Dr. Hitesh Jagani \& Dr. Nasheman Bandookwala / Page 399-410

\begin{tabular}{|c|c|c|c|c|c|c|}
\hline & & & & & & Agriculture \\
\hline & Male & Female & Male & Female & & \\
\hline (1) & (2) & (3) & (4) & $(5)$ & (6) & (7) \\
\hline $\mathrm{AP}$ & 0.180372 & 0.022398 & 0.224875 & 0.105541 & 0.124175 & 0.469333 \\
\hline Assam & 0.145964 & 0.112032 & 0.186697 & 0.141775 & 0.767532 & 0.759384 \\
\hline Bihar & 0.128003 & 0.047457 & 0.195467 & 0.165411 & 0.370752 & 0.846234 \\
\hline Gujarat & 0.036789 & 0.027635 & 0.128448 & 0.133329 & 0.751176 & 1.038001 \\
\hline Haryana & 0.439905 & 0.43456 & 0.43454 & (a) & 0.987849 & 0 \\
\hline Himachal Pradesh & 0.353257 & 0.38325 & 0.305424 & @ & 1.084906 & 0 \\
\hline $\mathrm{J} \& \mathrm{~K}$ & 0.480242 & @ & 0.480395 & @ & @ & 0 \\
\hline Karnataka & 0.163817 & 0.038087 & 0.20687 & 0.09667 & 0.232497 & 0.4673 \\
\hline Kerala & 1.002056 & 0.634235 & 1 & @ & 0.632934 & 0 \\
\hline MP & 0.040987 & 0 & 0.066918 & @ & @ & 0 \\
\hline Maharashtra & 0.142567 & 0.005194 & 0.184085 & 0.008993 & 0.03643 & 0.04885 \\
\hline Manipur & @ & $@$ & -0.22279 & @ & @ & 0 \\
\hline Meghalaya & 0.111123 & .0 .002921 & 0.171021 & (a) & 0.02629 & 0 \\
\hline Orissa & 0.099264 & 0.069119 & 0.111395 & 0.109369 & 0.696316 & 0.981818 \\
\hline Punjab & 0.334343 & & 0.305829 & @ & 0 & 0 \\
\hline Rajasthan & 0.264943 & 0.166133 & 0.302892 & @ & 0.627052 & 0 \\
\hline Tamil Nadu & 0.425817 & 0.117139 & 0.522785 & 0.285839 & 0.275093 & 0.546761 \\
\hline Tripura & 0.184159 & & 0.182282 & & 0 & 0 \\
\hline UP & 0.123523 & 0.065722 & 0.199781 & 0.137177 & 0.53206 & 0.686638 \\
\hline West Bengal & 0.170829 & 0.108937 & 0.181472 & 0.123081 & 0.6377 & 0.678237 \\
\hline India & 0.196494 & 0.064207 & 0.247924 & 0.125572 & 0.326762 & 0.506495 \\
\hline
\end{tabular}

Source Calculated

Pay parity as depicted in column 6 and 7 in the above table is worked out by dividing pay index of female with pay index of male for respective activity. Low level of equality is exhibited across states of India in both the activity in payments made to female vis.-a-vis. male. Infact perfect equality is only desirable. Pay parity for agricultural workers is calculated as 1 for Himachal Pradesh depicting no inequality in payment between male and femal in the state while for Non agricultural workers pay parity is calculated to be 0.759 in Assam depicting disparity of 0.241 and least among states of India. Gujarat records parity of 0.751 indicating disparity of 0.249 ie $24 \%$.

\section{Epilogue}

The study concludes inequality in payments exists in both the activity viz agricultural and non agricultural for female as against her male counterpart. Although corporate social responsibility 
(CSR) has been made mandatory across sectors that mandates female equality this discrimination sharply still exists. Moreover, not only are female paid less they are given lesser opportunity for promotion and growth in the organization- glass ceiling as popularly termed in management literature. In some activities although female are more efficient than male they are not preferred or promoted and hence women growth and empowerment remains a far fetched dream. Building fairer and more inclusive economies must be the goal of global, national and state leaders. To get there, instilling gender parity across all forms of economic participation will be critical. Fortunately, since last decade the pathways to accelerating gender parity have become more evident and Governments must create policies that provide talent development, integration and deployment of opportunities for both the gender. Additionally women participation in decision making in social and economic concerns of family is another crucial factors determining equality. We hope that the goal of equality is achieved earlier and much before the estimated year 2257 by WEF. However, to attain an equal society is herculean task and constant and conscious efforts on part of all stakeholders is inevitable.

\section{End notes :}

1) The OECD countries defines gender wage gap as the difference between male and female median wages divided by male median wages. Wages are expressed in Purchasing Power Parity terms and computed for full time employee

2) According to ILO difference between men and women median and mean wages is gender pay gap and is computed on hourly basis.

3) According WEF (2018) Iceland is on first rank with least gender pay gap having closed $85.5 \%$ of gender gap

4) In Economic opportunity and participation sub index India ranked $142^{\text {nd }}$

5) Unequal pay and Gender pay gap : Unequal pay refers to situations where women are paid less than men for doing the same work. The gender pay gap, on the other hand, is a measure of the gap in the overall earnings of men and women. It is calculated by considering several parameters applied to the total number of employed members of both genders.

6) The Unadjusted pay gap and the adjusted pay gap. The adjusted pay gap is simply differentiates between mean and median wages of the two genders, the adjusted pay gap takes into account differences in factors such as occupation, education and job experience.

7) Wage Inequality : When two individuals in a company do similar work at the same level of qualification yet are not paid equally, this is wage inequality. Such situations are illegal. They are considered discriminatory . This is same as unequal pay

8) Wage inequality is calculated in the study by dividing female wages to male wages and subtracting the same from 1 eg. For Tamil Nadu 179.03/321.67=0.556 1-0.556=0.443

9) Pay parity Index $=$ Actual value-Minimum value/maximum value- Minimum value . In 
the above data for agricultural activity maximum value is in Kerela for mem (587.95) and minimum value in the agricultural is in Madhya Pradesh female worker of 124.9

so, Pay parity inequality Index for Andrapradesh $=(208.25-124.9) /(587.95-124.9)=$ 0.180372 , then $0.0223 / 0.1803=0.124$

10) paycheck.in calculates gender pay gap in India on Age of employee, education of employee, experience of employee and occupation. 


\section{References}

Global Gender Gap report 2020, World economic forum

- Shayan Javed and Anupam Manuhar "Women and wage discrimination in India : A critical analysis"

- Selected socio economic indicators of states of India 2011

- Shantanu Khanna "Gender wage discrimination in India : Glass ceiling or Sticky floor ?" Department of Economics Delhi School of Economics Working paper no 214

- Gupta Nayni "Gender pay gap in last ten years- A case study of India" ORF working paper series, March 26, 2014,

- Mohanty Siba Shankar,Bhist Madhu and Mohpatra Purnima "Gender Wage Gap among Salaried Workers in India: Results of a Principal Component Analysis of State Level Statistics" DOI :10.5958/j 0976-4666.59.2.017

- Tushar Agrawal "Gender and caste based discrimination in India : Some recent evidences" Journal of labour market (2014) 47 pp 329-340

- Anindita Sengupta and Panchanan Das "Gender wage discrimination across social and religious groups in India” Economic and Political weekly Vol XLIX no 21 May 2014

- Nisha Srivastva and Ravi Srivastava "Women, work and employment outcomes in Rural India" Economic and Political Weekly, Vol 45,no 28 July 10-16 2010, pp 49-63

- Minna Salminen-Karlsson “ gender pay gapin IT sector in India” paperr presented at SASNET 2015 Conference: Structural Transformation in South Asia, 20-22 May 2015, Lund, Sweden.

https://www.payscale.com/data/gender-pay-gap

- https://www.livemint.com/money/personal-finance/what-is-gender-pay-gap-and-why-isit-so-wide-in-india-11575356633900

- https://economictimes.indiatimes.com/magazines/panache/gender-pay-gap-still-highwomen-in-india-earn-19-pc-less-than-men-report/articleshow/68302223.cms

- https://www.business-standard.com/article/current-affairs/gender-wage-gap-highest-inindia-women-are-paid-30-less-than-men-ilo-118112701048 1.html

$\checkmark$ https://www.siliconrepublic.com/careers/gender-gap-case-studies

\section{Dr. Hitesh N. Jagani \\ Assistant Professor \\ BRS (Rural Planning and Development)}

M. D. Gramsewa Sankul, Gujarat Vidyapith, Randheja Dist.: Gandhinagar

Mo.9428108588, Email: hitesh.jagani@gujaratvidyapith.org

\&

Dr. Nasheman Bandookwala

Assistant Professor 
Towards Excellence: An Indexed, Refereed \& Peer Reviewed Journal of Higher Education / Dr. Hitesh Jagani \& Dr. Nasheman Bandookwala / Page 399-410

\section{BA (Rural Economics)}

M. D. Gramsewa Sankul, Gujarat Vidyapith, Randheja Dist.: Gandhinagar Mo.8780653615, Email: nasheman@gujaratvidyapith.org 